\title{
Relationship Between Introversion/Extroversion Personality Trait and Proficiency in ESL Writing Skills
}

\author{
Sumaira Qanwal ${ }^{1} \&$ Mamuna Ghani ${ }^{1}$ \\ ${ }^{1}$ Department of English, The Islamia University of Bahawalpur, Pakistan \\ Correspondence: Sumaira Qanwal, Department of English, The Islamia University of Bahawalpur, Pakistan. \\ E-mail: qanwalsumaira1@gmail.com
}

\author{
Received: April 20, 2019 Accepted: May 17, 2019 Online Published: July 2, 2019 \\ doi:10.5539/ijel.v9n4p107 URL: https://doi.org/10.5539/ijel.v9n4p107
}

\begin{abstract}
The study aims at investigating the role of extroversion/introversion personality traits in learning writing skills of English as a second language. The selected sample for the research consisted of 57 participants who undertook instruction on 'Essay Writing and Presentation' for six months as a formal course of study in their MA English Program. The research tools consisted of a questionnaire and an achievement test on writing skills. The questionnaire consisted of 30 items all adopted from Eysenck's Personality Questionnaire to measure the introversion/extroversion traits of students' personality. After identifying their personality trait (i.e., introvert, extrovert and neurotic), the participants were given an achievement test on writing skills. The participants' scores in the achievement test were submitted to SPSS and independent sample t-test was applied. The findings reveal that a significant difference exists between the writing achievement of introvert and extrovert learner groups. However, no difference is found between the writing performance of neurotic and introvert learner groups or between neurotic and extrovert learner groups. The results also reveal that introverts are better learners of ESL writing skills as compared to the extroverts.
\end{abstract}

Keywords: introversion, extroversion, personality traits, proficiency in writing skills, English as a second language

\section{Introduction}

The procedure of learning a second/foreign language (SL/FL) uncovers incredible individual variability among learners. These individual differences are majorly categorized as cognitive, affective and personality variables. The cognitive group is identified with mental information processing including aptitude and intelligence; the affective variables include motivation and attitude; and the personality variables include introversion/extroversion, anxiety, self-esteem, risk-taking, tolerance, empathy and many others. The conviction that the individual differences of personality in general and the intro-extro dimensions in particular help learners' capability in English as a foreign language (EFL) is held by various researchers including Berry (2007), Dewaele and Furnham (1999), Kiany (1998), and Van Daele (2005).

Extroversion has generally been viewed as an accommodating attribute for language learning. In the 1970s, it was hypothesized by some connected linguists (Brown, 2000; Naiman, Fröhlich, Stern, \& Todesco, 1978; Skehan, 1989) that extroverts in comparison with introverts are better language learners since they make more chances to practice the language by exploiting the data they are furnished with and deliver more yield. Hence, it can be presumed that extroverts being higher yield generators should be fit for learning a FL more quickly than their contemplative partners.

On the other hand, many psychologists (e.g., Cook, 2002; Eysenck \& Eysenck, 1985; Kiany, 1998; Matthews \& Deary, 1998) hold the opinion that extroversion is somewhat a drawback in terms of learning a language. This supposition is focused around a solid biological ground that extroverts have lower level of cortical arousal, and in the meantime get more easily hindered which makes them more defenseless to mental diversion. Furthermore, they have a restricted long-term memory than introverts who profit from having a more extensive long-term memory span (Eysenck et al., 1981). These biologically decided diversities cause both groups to have diverse behavioral tendencies. Eysenck and Eysenck (1985) have additionally watched that it is introverts who attain superior academic achievement on composed tests in research as compared to extroverts, in this manner proposing that the previous are better language learners. 
Remembering these two angles, one can watch that there is an acceptable contradiction between the applied linguists' and the psychologists' opinions concerning the impacts of the intro-extro tendencies on general learning. As the few studies conducted so far have not delivered predictable results, the point of this study is to research these two angles more lucidly. Specifically, the present study will attempt to exhibit how the level of introversion and extroversion in the individual's personality influences learners' language proficiency. However, the study has been delimited by choosing only one of the areas of language proficiency, i.e., writing skills, to investigate the effect of intro-extro personality traits. Hence, the research questions are:

1) Is there any relationship between the ESL learners' personality traits and their potential for learning writing skills at Masters level?

2) What type of relationship exists between the intro-extro tendencies of the ESL learners and their performance in writing skills at Masters level?

\section{Literature Review}

\subsection{Eysenck's Theory of Personality}

Hans Eysenck, a German psychologist well-known for his experimental studies on the nature of personality, initially, was of the opinion that personality can be adequately described by two factors such as extroversion-introversion and neuroticism-stability. However, more recently, as a result of a series of factor analytic studies, he proposed the third dimension, namely psychoticism-normality. His scientific model of personality, commonly known as the PEN model (the acronym stands for Psychoticism, Extroversion, and Neuroticism) consists of a number of sub-traits which have been classified as belonging to the three universal dimensions. The three dimensions are explained by Matthews and Deary $(1998$, p. 25) in the following way:

Psychoticism $(P)$ involves people who are predisposed to be aggressive, cold, egocentric, impersonal, impulsive, anti-social, unsympathetic, manipulative, creative etc.

Extroversion $(E)$ is ascribed to people who tend to be sociable, active, assertive, dominant, irresponsible, risk-taking, sensation-seeking, expressive, and venturesome.

Neuroticism $(N)$ involves individuals who are inclined to be anxious, depressed, guilt-feeling, tense, moody, irrational, shy, and emotional.

What Eysenck et al. (1981) proposed is that a person is not classified as possessing only one of the three dimensions. Rather, he is likely to show some degree of each of these factors on the continuum.

Although Eysenck's picture of the personality traits appears to be unbiased, there is a generally observable tendency in various environments such as schools, peer groups, work places and many others to favour the extrovert behavior. The existence of such a situation has been observed by numerous researchers including Brown et al. (1973), Bush (1982), and Gardner (1978). However, Ausubel (1968, p. 413) emphasizes the fact that learners' introversion and extroversion may be "a grossly misleading index of social adjustment". What he implies is that the role of introversion and extroversion is often misinterpreted in language classes. This misconception results from the fact that teachers are inclined to take their pupils' behaviour at face value and categorize them according to the existing stereotypes, which very often turn out to be far from the truth. In the same way, Brown (2000) also seems to openly favour introversion by saying that introverts can have an inner strength of character that extroverts do not have.

\subsection{Research About Personality and Language Learning}

The biological basis of personality has indicated that introverts and extroverts have certain predispositions, albeit different, which may significantly contribute to the process of learning a SL/FL. However, we will limit our discussion to the relationship of personality traits with writing skills only

\subsubsection{Personality Traits and Writing Skills}

Contrary to the predictions of applied linguists, the advocates of Eysenck's theory are convinced that introverts are better language learners due to the fact that they possess "more mental concentration and can thus focus more on the task at hand" (Van Daele, 2005, p. 96). Ehrman and Oxford (1990) undertook a study in which they investigated what strategies were applied by 20 adult language learners with various style preferences. To define participants' psychological types, including the intro-extro dimension, the Myers-Briggs Type Indicator (MBTI), a personality testing instrument, was used. The authors' findings, among other things, indicated "some language learning advantage for introverts" (p. 323). When the researchers correlated students' scores obtained by means of MBTI with the scores on the Strategy Inventory for Language Learning (SILL), it showed that no correlations were found between extroversion and language learning strategy use. In view of this, it was concluded that 
introversion can be advantageous in a classroom where concentrated study and focus are required.

Another research in which the correlations between extroversion and scores on written performance tests appeared to be inversely significant, was the study undertaken by Carrell, Patricia, Gusti and Moneta (1996). A group of EFL students in Indonesia participated in a longitudinal study, one-semester long course which included a series of EFL language measures like non-standardized, monthly tests of reading, grammar, vocabulary and writing. The participants' personality types were measured by means of the MBTI instrument. The statistically significant difference between introverts and extroverts indicated that the former considerably outscored their extrovert peers when it comes to the end-of-course composite grades (Carrell et al., 1996, p. 94). The authors, surprised by the findings, recommended further research in this field.

Kiany (1998) in her study investigated the impact of the intro-extro dimension on academic achievement and L2 proficiency. Forty Iranian, non-English PhD students were involved in the research. The Iranian version of the EPQ was intended to measure the participants' degree of extroversion. Besides, standardized tests like TOEFL and IELTS were also used to measure the FL proficiency and the grade point averages (GPAs) for measuring academic achievements. The results indicated negative but non-significant correlations between extroversion and scores on the writing tests of the instruments mentioned above. The author concluded that introverts may have an advantage when it comes to the writing tests.

Carrell's (2002) study exposed that the writers' personality type affects the rating they get for their essays. Chamorro-Premuzic and Furnham (2003, a, b) uncovered significant relationships between intro-extro personality trait and academic performance. Chamorro-Premuzic, Furnham, Dissou and Heaven's (2005) study inferred that extrovert ESL learners are more comfortable with oral examination as compared to the written ones, and that they prefer to work in groups rather than alone. In another study, Erton (2010) showed that learning styles of extrovert students are different from those of the introverts leading to proficiency differences between the two. Widyastuti (2012) concluded that extroversion is positively correlated with L2 writing and vocabulary skills.

On the contrary, two other studies (Mansourinejad, Bijami, \& Ahmadi, 2012; Alavinia \& Hassanlou, 2014) indicated that no relationship exists between personality type and writing ability.

In an EFL based study, Shokrpour and Moslehi (2015) found no relationship between personality type and students' self and teacher correction techniques in writing.

However, Zafar, Khan and Meenakshi's (2017) research uncovered that intro-extro personality dimension is significantly correlated with language learning skills. According to this study, extroverts have an advantage on the introverts in speaking and reading skills while the latter perform better in listening skills. In case of writing skills, personality type does not seem to have any impact.

In Pakistani ESL context, Qurat-ul-Ain and Saeed's (2017) study showed that introverts outperform their extrovert counter parts in writing.

The aforementioned studies examined the relationship of intro-extro personality dimensions with language learning achievement in various worldwide contexts. As the above given discussion reveals, these studies came up with somewhat conflicting results regarding the impact of intro-extro personality on learning achievement in general. However, in terms of writing proficiency in particular, the studies have majorly proved introversion as being an advantage over extroversion. Therefore, the present study has tried to see the role of the personality traits in writing proficiency of second language learners in a different context, i.e. Pakistan in order to counter-test the findings of the previous research on the subject.

Furthermore, after reviewing the abovementioned studies, it seems that second language learning research has focused more on examining intro-extro personality traits, while the role of intermediary personality dimension, i.e., neuroticism has not been given its due consideration. Henceforth, besides comparing the impact of introversion and extroversion on writing skills, the present study has included the third dimension, i.e., neuroticism also in the circumference of its investigation.

\section{Research Methodology}

\subsection{Research Sample}

The research population involved the students of MA English at a public sector university of Punjab, Pakistan. Cluster sampling was adopted as a sampling technique for the present study. A group of the first semester MA English students was selected as sample. These students had undertaken instruction on "Essay Writing and Presentation Skills" as a course for five months. The class consisted of 71 students. Out of these 71 students 57 
showed their willingness to participate in the study. Hence, they were selected as participants for the present research study.

\subsection{Research Tools}

Two research tools (a questionnaire and an achievement test of writing skills) were used to collect data for the study.

\subsubsection{Questionnaire}

Eysenck's personality questionnaire (Eysenck \& Eysenck, 1975) was used to identify personality traits of the participants (i.e., introvert, neurotic and extrovert). However, only 30 items of Eysenck's personality questionnaire were adopted and included in the questionnaire for the present study. Only those items which were specifically meant to measure introversion/extroversion aspects of the participants' personality were selected from the original Eysenck's personality questionnaire.

\subsubsection{Achievement Test}

The achievement test comprised of an essay writing task. This test was used both as a pre-test and post-test. At the beginning of the course, the selected participants were asked to write an essay on "A Memorable Function" in 40 minutes. The rationale behind choosing the said topic was to assign a personal writing task which would supply them with an easily retrievable content from their subjective experience, as the purpose was just to assess their writing skills and not to judge their knowledge on a specific subject area. Further, it was expected that the narrative nature of the topic would expose their command on grammar and the use of appropriate vocabulary in the target language. The time duration of 40 minutes was allocated with a purpose to give them sufficient time for brain storming (approx. 5-7 minutes,) pre-writing/mind mapping (approx. 5-7 minutes) and final draft (approx. 25-30 minutes). The essay was of total 20 marks. The students' performance in the test was to be judged on the basis of vocabulary (5 marks), spelling \& grammar ( 5 marks), content (5 marks) and expression (5 marks). The aim was to judge the status of proficiency in writing skills in English as a second language before taking the formal course on essay writing skills.

Later, when the course was completed, the participants were again asked to write an essay on the same topic 'a memorable function'. The purpose was to measure their current proficiency in writing skills and to compare it with the previous one.

\subsection{Data Analysis Procedure}

The data were analyzed in two stages. First, the data based on Eysenck's personality questionnaire were analyzed manually by taking mean scores, thus, dividing the students in three groups based on their personality traits, i.e., Extroverts, Neurotics and Introverts. Secondly, data obtained in the form of the participants' scores in pre and post writing tests were analyzed by using paired samples statistics and independent sample $\boldsymbol{t}$-test in SPSS Inferences and conclusions were drawn systematically on the basis of statistics provided by SPSS.

\section{Data Analysis}

\subsection{Analysis of Personality Questionnaire}

The data collected through the questionnaire were analyzed manually by using the statistical technique of deriving arithmetic mean against each statement. The following formula was used to get the arithmetic mean:

$$
\mathrm{M}=\frac{\Sigma f x}{N}
$$

Where

$\mathrm{M}=$ Arithmetic mean

$\sum f x=$ Sum of the mid points/scores obtained by the students on a given answer weighed by their frequencies/answers

$\mathrm{N}=$ Total number of responses made by participant on a questionnaire

Using this formula, a participant's mean score for each of 30 statements (whose responses were collected on 5-point Likert scale ranging from strongly disagree to strongly agree) was calculated. Following this, the participant's total mean score on the questionnaire was obtained by computing the average of his/her 30 mean score values. The purpose was to get familiar with personality trait of the participants. The following results were obtained. 
Table 1. Participants' scores on EPQ and their personality type

\begin{tabular}{lllll}
\hline Mean Score range on EPQ & Personality Type & Frequency & $\%$ age & N \\
\hline $1.0-2.5$ & Introversion & 14 & 24 & 57 \\
$2.6-3.5$ & Neuroticism & 15 & 27 & \\
$3.6-5.0$ & Extroversion & 28 & 49 & \\
\hline
\end{tabular}

Table 1 shows that out of 57 participants, 14 were found to be introverts (mean score 1.0-2.5), 15 neurotics (mean score 2.6-3.5), and 28 extroverts (mean score 3.6-5.0).

\subsection{Analysis of Achievement Test (Writing Skills)}

The participants' written essays ware graded for their use of vocabulary, spelling and grammar, content and expression. The scores on each of the four parameters ranged from 0 to 5. Following the below given key (Table 2), total mean score for each personality group's (i.e., introverts, neurotics and extroverts) performance in the four parameters of writing (vocabulary, spelling and grammar, content and expression) was calculated statistically to know its overall proficiency in each domain.

Table 2. Key for determining proficiency levels

\begin{tabular}{ll}
\hline Proficiency level & Mean Score \\
\hline Poor & $0-2.0$ \\
Satisfactory & $2.1-3.0$ \\
Average & $3.1-3.5$ \\
Good & $3.6-4.0$ \\
Exceptional & $4.1-5.0$ \\
\hline
\end{tabular}

The obtained results for the mean scores of extroverts, neurotics and introvert learner groups in the four parameters of writing proficiency are given in the Tables 3-6.

Table 3a. Scores of vocabulary (pre-test)

\begin{tabular}{|c|c|c|c|c|c|c|c|c|c|}
\hline & \multicolumn{3}{|c|}{ Extroverts } & \multicolumn{3}{|c|}{ Neurotics } & \multicolumn{3}{|c|}{ Introverts } \\
\hline & Freq & Percent & Mean & Freq & Percent & Mean & Freq & Percent & Mean \\
\hline Satisfactory & 13 & & 2.75 & 5 & & 2.93 & 6 & & 2.85 \\
\hline Average & 10 & & & 6 & & & 4 & & \\
\hline Good & 4 & & & 4 & & & 4 & & \\
\hline Exceptional & 1 & & & 0 & & & 0 & & \\
\hline Total & 28 & & & 15 & & & 14 & & \\
\hline
\end{tabular}

Table 3a shows participants' scores in pre-test vocabulary. Extroverts' mean scores, i.e., 2.75, shows them to be at 'satisfactory' level of competence in using appropriate vocabulary in writing. While the neurotics' and introverts' mean scores, i.e., 2.93 and 2.85 respectively imply that vocabulary skill of both groups is also of 'satisfactory' level, but a little better that of extroverts. So, the inference is made that performance of introverts in terms of vocabulary is better than the extroverts but almost similar to that of neurotics.

Table 3b. Scores of vocabulary (post-test)

\begin{tabular}{llllllllll}
\hline & \multicolumn{2}{l}{ Extroverts } & \multicolumn{3}{c}{ Neurotics } & \multicolumn{3}{c}{ Introverts } \\
\cline { 2 - 9 } & Freq & Percent & Mean & Freq & Percent & Mean & Freq & Percent & Mean \\
\hline Satisfactory & 5 & 17.9 & $\mathbf{3 . 4 6}$ & 0 & 0 & $\mathbf{3 . 8 0}$ & 1 & 7.1 & $\mathbf{3 . 9 3}$ \\
Average & 9 & 32.1 & & 3 & 20.0 & & 1 & 7.1 & \\
Good & 10 & 35.7 & & 12 & 80.0 & & 10 & 71.4 \\
Exceptional & 4 & 14.3 & & 0 & 0 & & 2 & 14.3 \\
Total & 28 & 100.0 & & 15 & 100.0 & & 14 & 100 \\
\hline
\end{tabular}

Table $3 b$ shows participants' scores in post-test vocabulary. Extroverts' mean scores, i.e., 3.46, shows them to be at 'average' level of competence in using appropriate vocabulary in writing. While the neurotics' and introverts' 
mean scores, i.e., 3.80 and 3.93 respectively imply that vocabulary skill of both groups is 'good'. So, the inference is made that performance of introverts in terms of vocabulary is better than the extroverts but almost similar to that of neurotics.

Table 4a. Score of grammar (pre-test)

\begin{tabular}{|c|c|c|c|c|c|c|c|c|c|}
\hline & \multicolumn{3}{|c|}{ Extroverts } & \multicolumn{3}{|c|}{ Neurotics } & \multicolumn{3}{|c|}{ Introverts } \\
\hline & Freq & Percent & Mean & Freq & Percent & Mean & Freq & Percent & Mean \\
\hline Satisfactory & 11 & & 2.89 & 7 & & 2.66 & 8 & & 2.71 \\
\hline Average & 9 & & & 6 & & & 2 & & \\
\hline Good & 8 & & & 2 & & & 4 & & \\
\hline Exceptional & 0 & & & 0 & & & 0 & & \\
\hline Total & 28 & 100.0 & & 15 & 100.0 & & 14 & 100.0 & \\
\hline
\end{tabular}

The statistics of Table 4a reveal the command of the participants on pre-test grammar. Mean scores 2.89, 2.66 and 2.71 respectively indicate 'satisfactory' competence of all groups in the field of grammar. However, extroverts score is a little better than the other two groups.

Table 4b. Scores of grammar (post-test)

\begin{tabular}{llllllllll}
\hline & \multicolumn{2}{l}{ Extroverts } & \multicolumn{3}{c}{ Neurotics } & \multicolumn{3}{c}{ Introverts } \\
\cline { 2 - 9 } & Freq & Percent & Mean & Freq & Percent & Mean & Freq & Percent & Mean \\
\hline Satisfactory & 11 & 39.3 & $\mathbf{2 . 9 3}$ & 1 & 6.7 & $\mathbf{3 . 0 7}$ & 2 & 14.3 & $\mathbf{3 . 3 6}$ \\
Average & 8 & 28.6 & & 12 & 80.0 & & 5 & 35.7 & \\
Good & 9 & 32.1 & & 2 & 13.3 & & 7 & 50.0 \\
Exceptional & 0 & 0 & & 0 & 0 & & 0 & 0 \\
Total & 28 & 100.0 & & 15 & 100.0 & & 14 & 100 \\
\hline
\end{tabular}

The statistics of Table $4 \mathrm{~b}$ reveal the command of the participants on post-test grammar. Mean scores 2.93, 3.07 and 3.36 respectively indicate 'satisfactory' competence of the extroverts and 'average' competence of the neurotics and introverts in the field of grammar.

Table 5a. Scores of content (pre-test)

\begin{tabular}{|c|c|c|c|c|c|c|c|c|c|}
\hline & \multicolumn{3}{|c|}{ Extroverts } & \multicolumn{3}{|c|}{ Neurotics } & \multicolumn{3}{|c|}{ Introverts } \\
\hline & Freq & Percent & Mean & Freq & Percent & Mean & Freq & Percent & Mean \\
\hline Satisfactory & 11 & & 2.96 & 5 & & 2.80 & 6 & & 3.00 \\
\hline Average & 7 & & & 8 & & & 3 & & \\
\hline Good & 10 & & & 2 & & & 4 & & \\
\hline Exceptional & 0 & & & 0 & & & 1 & & \\
\hline Total & 28 & & & 15 & & & 14 & & \\
\hline
\end{tabular}

The findings of Table 5a explain the extent to which the participants are committed to follow the content while writing a pre-test manuscript. The extroverts' and neurotics mean score 2.96 and 2.80 shows them to be 'satisfactory' at content selection, while the introverts' mean scores, being 3.00, implies an 'average command' command on content selection in the pre-test.

Table 5b. Scores of content (post-test)

\begin{tabular}{llllllllll}
\hline & \multicolumn{2}{l}{ Extroverts } & \multicolumn{3}{l}{ Neurotics } & \multicolumn{3}{l}{ Introverts } \\
\cline { 2 - 10 } & Freq & Percent & Mean & Freq & Percent & Mean & Freq & Percent & Mean \\
\hline Satisfactory & 1 & 3.6 & $\mathbf{3 . 8 9}$ & 9 & 0 & $\mathbf{4 . 1 3}$ & 0 & 0 & $\mathbf{4 . 4 3}$ \\
Average & 7 & 25.0 & & 4 & 26.7 & & 1 & 7.1 & \\
Good & 14 & 50.0 & & 5 & 33.3 & & 6 & 42.9 \\
Exceptional & 6 & 21.4 & & 6 & 40.0 & & 7 & 50.0 \\
Total & 28 & 100.0 & & 15 & 100.0 & & 14 & 100 & \\
\hline
\end{tabular}


The findings of Table $5 \mathrm{~b}$ explain the extent to which the participants are committed to follow the content while writing a post-test manuscript. The extroverts' mean score 3.89 shows them to be 'good' at content selection, while the neurotics' and introverts' mean scores, being 4.13 and 4.43 respectively, imply an 'exceptional' command on content selection in the post test.

Table 6a. Scores of expression (pre-test)

\begin{tabular}{|c|c|c|c|c|c|c|c|c|c|}
\hline & \multicolumn{3}{|c|}{ Extroverts } & \multicolumn{3}{|c|}{ Neurotics } & \multicolumn{3}{|c|}{ Introverts } \\
\hline & Freq & Percent & Mean & Freq & Percent & Mean & Freq & Percent & Mean \\
\hline Satisfactory & 12 & & 2.75 & 6 & & 2.86 & 4 & & 2.78 \\
\hline Average & 12 & & & 5 & & & 9 & & \\
\hline Good & 3 & & & 4 & & & 1 & & \\
\hline Exceptional & 1 & & & 0 & & & 0 & & \\
\hline Total & 28 & 100.0 & & 15 & 100.0 & & 14 & 100 & \\
\hline
\end{tabular}

Table 6a displays the extent to which the participants' written expression in the pre-test appeals the reader. Mean score 2.75 shows the tendency of all groups towards 'satisfactory' stage in expression of their feelings and messages. However, neurotics' mean scores (2.78) proves them to be a little better than the other two groups at expressing their ideas in written text.

Table 6b. Scores of expression (post-test)

\begin{tabular}{llllllllll}
\hline & \multicolumn{2}{l}{ Extroverts } & \multicolumn{3}{c}{ Neurotics } & \multicolumn{3}{c}{ Introverts } \\
\cline { 2 - 10 } & Freq & Percent & Mean & Freq & Percent & Mean & Freq & Percent & Mean \\
\hline Satisfactory & 5 & 17.9 & $\mathbf{3 . 4 6}$ & 1 & 6.7 & $\mathbf{3 . 7 3}$ & 0 & 0 & $\mathbf{3 . 9 3}$ \\
Average & 11 & 39.3 & & 4 & 26.7 & & 3 & 21.4 & \\
Good & 6 & 21.4 & & 8 & 53.3 & & 9 & 64.3 \\
Exceptional & 6 & 21.4 & & 2 & 13.3 & & 2 & 14.3 \\
Total & 28 & 100.0 & & 15 & 100.0 & & 14 & 100 \\
\hline
\end{tabular}

Table $6 \mathrm{~b}$ displays the extent to which the participants' written expression appeals the reader. Mean score 3.46 shows the tendency of the extroverts towards 'average' stage in expression of their feelings and messages. On the other hand, neurotics' and introverts' mean scores (3.73 and 3.93 respectively) prove them to be 'good' at expressing their ideas in written text.

Table 7a. Overall scores (pre-test)

\begin{tabular}{llllllllll}
\hline & \multicolumn{3}{l}{ Extroverts } & \multicolumn{3}{c}{ Neurotics } & \multicolumn{3}{c}{ Introverts } \\
\cline { 2 - 9 } & Freq & Percent & Mean & Freq & Percent & Mean & Freq & Percent & Mean \\
\hline Satisfactory & 0 & 0 & $\mathbf{2 . 5 3}$ & 0 & 0 & $\mathbf{2 . 5 3}$ & 0 & 0 & $\mathbf{2 . 6 4}$ \\
Average & 16 & 57.1 & & 8 & 53.3 & & 7 & 50.0 & \\
Good & 9 & 32.1 & & 6 & 40.0 & & 5 & 35.7 \\
Exceptional & 3 & 10.7 & & 1 & 6.7 & & 2 & 14.3 \\
Total & 28 & 100.0 & & 15 & 100.0 & & 14 & 100 \\
\hline
\end{tabular}

Table 7a presents participants' overall scores in the pre-test of writing skills. The extroverts', neurotics and introverts' mean scores $(2.53,2.53$ and 2.64 respectively) indicate that all groups' overall performance in the writing skills is of satisfactory level. However, introverts' performance is a little better in writing skills than that of the other two groups.

Table 7b. Overall scores (post-test)

\begin{tabular}{llllllllll}
\hline & \multicolumn{2}{l}{ Extroverts } & \multicolumn{2}{c}{ Neurotics } & \multicolumn{3}{c}{ Introverts } \\
\cline { 2 - 9 } & Freq & Percent & Mean & Freq & Percent & Mean & Freq & Percent & Mean \\
\hline Satisfactory & 0 & 0 & $\mathbf{2 . 8 2}$ & 0 & 0 & $\mathbf{3 . 0 7}$ & 0 & 0 & $\mathbf{3 . 2 1}$ \\
Average & 13 & 46.4 & & 1 & 6.7 & & 2 & 14.3 & \\
Good & 7 & 25.0 & & 12 & 80.0 & & 7 & 50.0 \\
Exceptional & 8 & 28.6 & & 2 & 13.3 & & 5 & 35.7 \\
Total & 28 & 100.0 & & 15 & 100.0 & & 14 & 100 \\
\hline
\end{tabular}


Table $7 \mathrm{~b}$ explains participants' overall scores in the post-test of writing skills. The extroverts' mean scores (2.82) indicates that their performance in the post-test writing is of satisfactory level. On the other hand, neurotics' and introverts' introverts' performance in the post test of writing is of average level. Still, introverts' skill in writing is a little better than that of neurotics.

\subsection{Difference Between Extrovert and Neurotic}

After comparing the three personality groups' mean scores in writing, the differences between each two groups' proficiency were measured statistically by applying independent samples t-test. The results are produced in Tables 8-13.

Table 8. Group statistics

\begin{tabular}{lllll}
\hline Group Statistics & & & \\
\hline & Personality trait of the participants & N & Mean & Std. Deviation \\
\hline Grand Total & Extrovert & $\mathbf{2 8}$ & $\mathbf{1 3 . 7 5 0 0}$ & $\mathbf{3 . 0 3 8 3 4}$ \\
& Neurotic & $\mathbf{1 5}$ & $\mathbf{1 4 . 7 3 3 3}$ & $\mathbf{1 . 9 0 7 3 8}$ \\
\hline
\end{tabular}

Table 9. Independent sample test

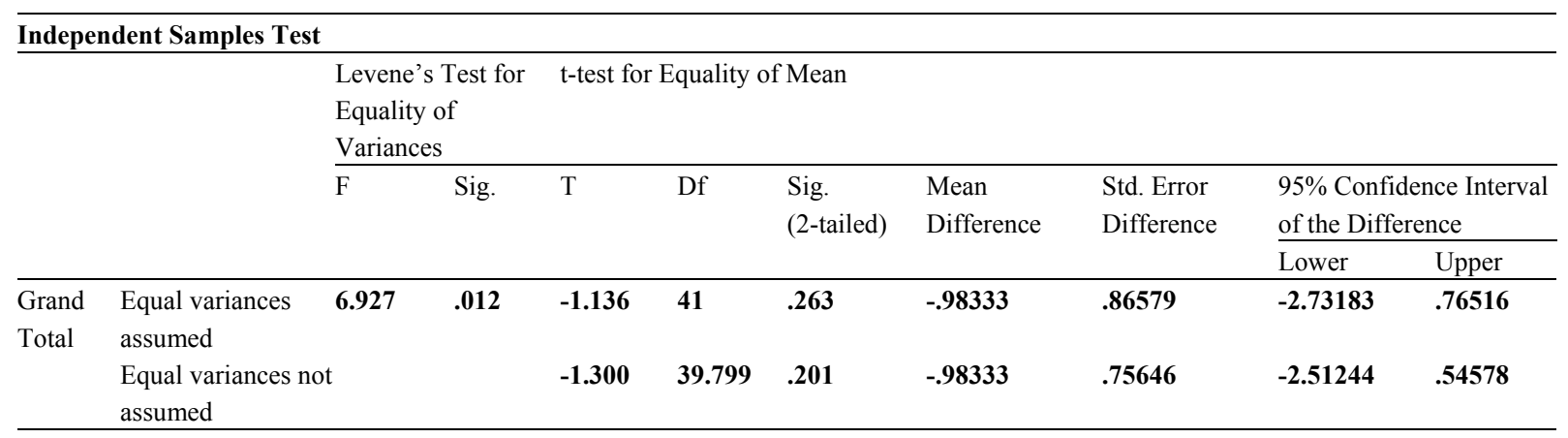

Tables 8 and 9 show group statistics as well as independent sample t-test. The statistics show that there are 28 participants in the extrovert group and 15 in the neurotic. Mean score is 13.75 and 14.73 respectively for the extrovert and neurotic groups. In (sig.) column of Table 9, $\mathrm{P}$ value is 0.012 which is less than 0.05 . Hence, we have to consider values of the second row (Equal variances not assumed) for analysis. Here, degree of freedom (Df) is at 39.8 and $\mathrm{P}$ value sig. (2-tailed) is at 0.201 that is more than the level 0.05 , so the hypothesis "Extroverts are significantly different from neurotics in linguistic competence in writing" is rejected.

\subsection{Difference Between Neurotic and Introvert}

Table 10. Group Statistics

\begin{tabular}{lllll}
\hline Group Statistics & & & \\
\hline & Personality trait of the Participants & N & Mean & Std. Deviation \\
\hline Grand Total & Neurotic & $\mathbf{1 5}$ & $\mathbf{1 4 . 7 3 3 3}$ & $\mathbf{1 . 9 0 7 3 8}$ \\
& Introvert & $\mathbf{1 4}$ & $\mathbf{1 5 . 6 4 2 9}$ & $\mathbf{2 . 4 0 5 3 5}$ \\
\hline
\end{tabular}

Table 11. Independent sample test

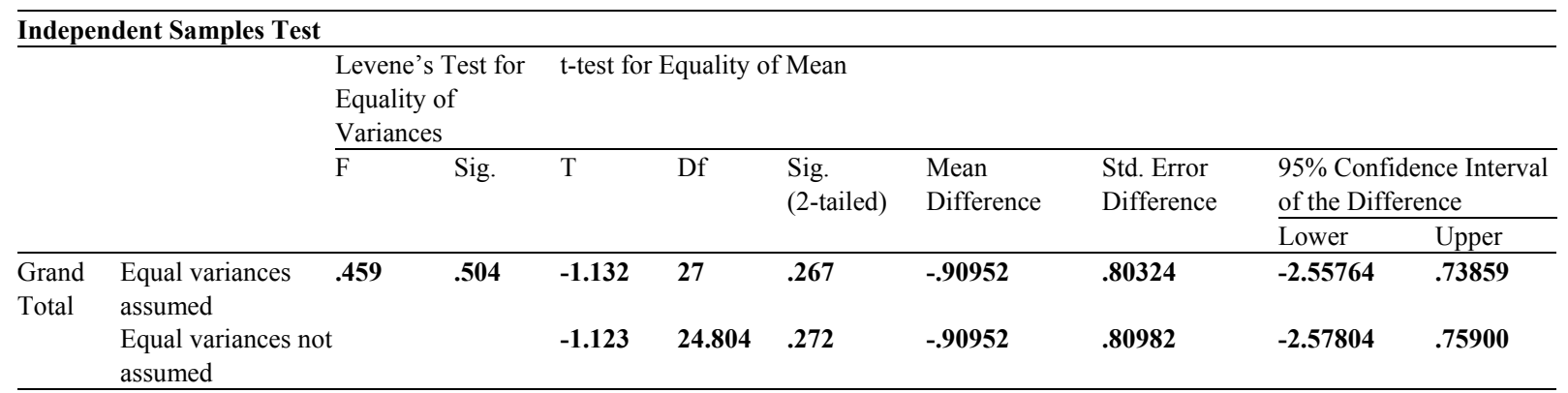


Tables 10 and 11 show group statistics as well as Independent Sample t-test. Statistics show that there are 15 participants in the neurotic group and 14 in the introvert. Mean is 14.73 and 15.64 respectively for the neurotic and introvert groups. In Significance column of Table 11, P value is at 0.459 which is more than 0.05 . Hence, we have to consider values of the first row (Equal variances assumed) for analysis. Here degree of freedom (Df) is at 27 and $\mathrm{P}$ value sig. (2-tailed) is at 0.267 that is more than the level 0.05 , so the hypothesis "Introverts are significantly different from neurotics in linguistic competence in writing" is rejected.

\subsection{Correlation Between Extrovert and Introvert}

Table 12. Group statistics

\begin{tabular}{lllll}
\hline Group Statistics & & & \\
\hline & Personality Trait of the Participants & $\mathrm{N}$ & Mean & Std. Deviation \\
\hline Grand Total & Extrovert & $\mathbf{2 8}$ & $\mathbf{1 3 . 7 5 0 0}$ & $\mathbf{3 . 0 3 8 3 4}$ \\
& Introvert & $\mathbf{1 4}$ & $\mathbf{1 5 . 6 4 2 9}$ & $\mathbf{2 . 4 0 5 3 5}$ \\
\hline
\end{tabular}

Table 13. Independent sample test

\begin{tabular}{|c|c|c|c|c|c|c|c|c|c|c|}
\hline \multicolumn{11}{|c|}{ Independent Samples Test } \\
\hline & & \multicolumn{2}{|c|}{$\begin{array}{l}\text { Levene's Test for } \\
\text { Equality of } \\
\text { Variances }\end{array}$} & \multicolumn{7}{|c|}{ t-test for Equality of Mean } \\
\hline & & \multirow[t]{2}{*}{$\mathrm{F}$} & \multirow[t]{2}{*}{ Sig. } & \multirow[t]{2}{*}{$\mathrm{T}$} & \multirow[t]{2}{*}{$\mathrm{Df}$} & \multirow[t]{2}{*}{$\begin{array}{l}\text { Sig. } \\
\text { (2-tailed) }\end{array}$} & \multirow[t]{2}{*}{$\begin{array}{l}\text { Mean } \\
\text { Difference }\end{array}$} & \multirow[t]{2}{*}{$\begin{array}{l}\text { Std. Error } \\
\text { Difference }\end{array}$} & \multicolumn{2}{|c|}{$\begin{array}{l}95 \% \text { Confidence Interval } \\
\text { of the Difference }\end{array}$} \\
\hline & & & & & & & & & Lower & Upper \\
\hline Grand & Equal variances assumed & 2.828 & .100 & -2.030 & 40 & .049 & -1.89286 & .93226 & -3.77702 & -.00870 \\
\hline Total & $\begin{array}{l}\text { Equal variances not } \\
\text { assumed }\end{array}$ & & & -2.196 & 32.161 & .035 & -1.89286 & .86195 & -3.64825 & -.13746 \\
\hline
\end{tabular}

Tables 12 and 13 show group statistics as well as independent sample $t$-test. Statistics show that there are 28 participants in the extrovert group and 14 in the introvert. Mean is 13.75 and 15.64 respectively for the extrovert and introvert groups. In (sig.) column of Table 13, $\boldsymbol{P}$ value is at 0.100 which is more than 0.05 . So, we need to consider statistics of the first row (Equal variances assumed) for analysis. Here degree of freedom (Df) is at 40 and $\boldsymbol{P}$ value sig. (2-tailed) is at 0.049 that is less than the level 0.05 , so the hypothesis "Extroverts are significantly different from introverts in linguistics competence in writing" is accepted.

\section{Findings}

The results of the study show that the extrovert learners were found at the average level of vocabulary usage as well as expression. Their content was good enough but their grammatical competence was only satisfactory. Neurotic learners' performance was found to be satisfactory in their grammatical structure, while their usage of appropriate vocabulary and clear expression were found to be good. Introverts also showed comparatively low performance in grammar but the other fields like vocabulary, content, and expression were found to be good and exceptional. Although no major differences were observed in the overall performance of the extrovert, neurotic and introvert learner groups, the introverts showed a tendency to be more proficient in writing than the extroverts.

The idea that the extroverts are significantly different from the neurotics in their competence in writing skills could not be verified because no significant difference was found between extroverts and neurotics in the t-test. Here neurotics seemed a little better than extroverts in writing. It was seen that the neurotics showed good use of vocabulary items. Their performance was good in terms of content but weak in grammar. On the other hand, the extroverts were weak in their choice of vocabulary and grammatical structure but stronger in their expression and content.

The idea that the introverts are significantly different from the neurotics in their competence in writing skills was also not confirmed as the findings showed no significant difference between the introverts and the neurotics. The introverts were weak in grammar but strong in some other aspects such as the choice of vocabulary, expression, and content. Same was the case with the neurotics. Though there was a little difference between their mean scores, the $\boldsymbol{p}$ value sig. ( 2 tailed) 0.459 was more than 0.05 . Hence, the idea that the introverts are significantly different from the neurotics in their competence in writing skill could not be confirmed in the present study. 
The idea that the introverts are significantly different from the extroverts in their competence in writing skills was positively confirmed in the context of the present study because in the processing of independent sample $\boldsymbol{t}$-test, $\boldsymbol{p}$ value sig. ( 2 tailed) was 0.049 which is below 0.05 showing that the introverts' scores in writing were significantly different from that of the extroverts. Major differences were seen in the choice of vocabulary and grammatical structure, whereas minor difference was seen at the level of content. Overall, the introverts seemed better in every field.

\subsection{Findings Based on Research Questions}

The study was based on two research questions:

1) Is there any relationship between the ESL learners' personality traits and their potential for learning writing skills at Masters level?

It was found that there is a strong relation between the personality traits of the learners and their potential for learning writing skills of English as a second language.

2) What type of relationship exists between the intro-extro tendencies of the ESL learners and their performance in the writing skills at Masters level?

The present study has revealed that a positive relationship exists between introvert personality trait and proficiency in ESL writing skills i.e. the introverts are better learners of writing skills as compared to the extroverts.

\section{Conclusion}

The present study shows that the introverts are better learners in terms of writing skills. It assimilates Eysenck's theory that introverts are better language learners due to the fact that they possess "more mental concentration and can thus focus more on the task at hand" (Van Daele 2005, p. 96). This capability, according to Eysenck (1974), makes them the prime candidate for successful learning. The results of this study are in agreement with the Eysenck's views appeared in 1974. They also stand in line with Premuzic et al.'s (2005), Widyastuti's (2012) and Qurat-ul-Ain and Saeed' (2017) studies which indicated that writing performance is positively affected by introvert dimension of personality.

However, the results of this study stand contrary to what was found by Brown (2000), Naiman et al. (1978), and Skehan (1989), who claimed that the extroverts are better language learners since they make more chances to practice the language by exploiting the external data they are furnished with. The findings are also in contradiction to Mansourinejad et al.'s (2012), Alavinia and Hassanlou's (2014), Shokrpour and Moslehi's (2015) and Zafar et al.'s (2017) studies which found no relationship between personality type and writing skills.

On the basis of the results obtained from the present study, it can be said that language learning is associated with the personality traits and that the introverts are better learners of writing skills as compared to the extroverts.

\section{References}

Alavinia, P., \& Hassanlou, A. (2014). On the viable linkages between extroversion/introversion and academic Iranian EFL learners' writing proficiency. English Language Teaching, 7(3), 167-175. https://doi.org/10.5539/elt.v7n3p167

Ausubel, P. D. (1968). Educational psychology: A cognitive view. New York: Holt, Rinehart and Winston.

Berry, V. (2007). Personality differences and oral test performance. Frankfurt: Peter Lang.

Brown, H. D. (2000). Principles of language learning and teaching (4th ed.). New York: Longman.

Brown, H. D., John C., King, H. V., Luther, G. E., \& Wardhaugh, R. (1973). Affective variables in second language acquisition. Language Learning, 23(2), 231-244. https://doi.org/10.1111/j.1467-1770.1973.tb00658.x

Bush, D. (1982). Introversion-extraversion and the EFL proficiency of Japanese students. Language Learning, 32(1), 109-133. https://doi.org/10.1111/j.1467-1770.1982.tb00521.x

Carrell, L., Patricia, Gusti G. A., \& Moneta S. P. (1996). Personality types and language learning in an EFL context. Language Learning, 46(1), 75-99. https://doi.org/10.1111/j.1467-1770.1996.tb00641.x

Carrel, P. L. (2002). The effect of writer's personalities and raters' personalities on the holistic evaluation of writing. Assessing Writing, 2(2), 153-190. https://doi.org/10.1016/1075-2935(95)90011-X

Chamorro-Premuzic, T., \& Furnham, A. (2003a). Personality predicts academic performance: Evidence from 
two longitudinal university samples. Journal of Research in Personality, 37(4), 319-338. https://doi.org/10.1016/S0092-6566(02)00578-0

Chamorro-Premuzic, T., \& Furnham, A. (2003b). Personality traits and academic examination performance. European Journal of Personality, 17(3), 237-250. https://doi.org/10.1002/per.473

Chamorrow-Premuzic, T., Furnham, A., Dissou, G., \& Heavon, P. (2005). Personality and preference for academic assessment: a study with Australian university students. Learning and Individual Differences, 15(4), 247-256. https://doi.org/10.1016/j.lindif.2005.02.002

Cook, V. (2002). Portraits of the L2 user. Clevedon: Multilingual Matters Ltd. https://doi.org/10.21832/9781853595851

Dewaele, J., \& Furnham, A. (1999). Extraversion: The unloved variable in applied linguistic research. Language Learning, 49(3), 509-535. https://doi.org/10.1111/0023-8333.00098

Ehrman, M., \& Oxford, R. (1990). Adult language learning styles and strategies in an intensive training setting. The Modern Language Journal, 74, 311-327. https://doi.org/10.1111/j.1540-4781.1990.tb01069.x

Erton, I. (2010). Relations between personality traits, language learning styles and success in foreign language achievement. Journal of Education, 38, 115-126.

Eysenck, J. H. (1974). Eysenck on extraversion. Oxford: Halsted Press.

Eysenck, J. H., \& Eysenck, M. W. (1985). Personality and individual differences: A natural science approach. New York: Plenum Press. https://doi.org/10.1007/978-1-4613-2413-3

Eysenck, H. J., Eysenck, M. W., Fulker, D. W., Gray, J., Levey, A. B., Martin, I., Powell, G. E., Stelmack, R. M., \& Wilson, G. (1981). A model for personality. Berlin: Springer Verlag. https://doi.org/10.1007/978-3-642-67783-0

Eysenck, J. H., \& Eysenck, S. B. G. (1975). Manual of the Eysenck Personality Questionnaire. London: Hodder and Stoughton. https://doi.org/10.1037/t05462-000

Furnham, A., Eysenck, B. G., \& Saklofske, D. H. (2008). The Eysenck personality measures: Fifty years of scale development. In G. J. Boyle, G. Matthews \& D. H. Saklofske (Eds.), The SAGE handbook of personality theory and assessment: Personality measurement and testing (Vol. 2, pp. 197-216). London: SAGE Publications.

Gardner, H. (1978). Developmental psychology: An introduction. Boston: Little Brown and Company.

Kiany, G. R. (1998). English proficiency and academic achievement in relation to extraversion: a preliminary study. International Journal of Applied Linguistics, 8(1), 113-128. https://doi.org/10.1111/j.1473-4192.1998.tb00123.x

Mansourinejad, A., Bijami, M., \& Ahmadi, M. R. (2012). Do personality traits predict academic writing ability? An EFL case study. English Linguistics Research, 1(2), 145-152. https://doi.org/10.5430/elr.v1n2p145

Matthews, G., \& Deary, I. J. (1998). Personality traits. Cambridge: Cambridge University Press.

Naiman, N., Fröhlich, M., Stern, H. H., \& Todesco, A. (1978). The good language learner. Clevedon: Multilingual Matters Ltd.

Qurat-ul-Ain, \& Saeed, S. (2017). Relationship of personality and writing skills among EFL learners at post-graduation level. Asian Innovative Journal of Social Sciences and Humanities, 1(1), 12-25.

Shokrpour, N., \& Moslehi, S. (2015). The Relationship between Personality Types and the Type of Correction in EFL Writing Skill. Pertanika Journal of Social Sciences \& Humanities, 23(1).

Skehan, P. (1989). Individual differences in second language learning. London: Edward Arnold.

Van Daele, S. (2005). The effect of extraversion on L2 oral proficiency. De Linguistica Aplicada a la Comunicacion, 24, 91-114. https://doi.org/10.1075/eurosla.6.13dae

Widyastuti, O. (2012). A correlational study between extroversion, vocabulary mastery, and writing ability of the tenth-grade students of SMA Negeri 4 Surakarta in the academic year of 2011/2012. Unpublished Thesis, Sebelas Maret University, Indonesia.

Zafar, S., Khan, Z. A., \& Meenakshi, K. (2017). Extraversion-Introversion Tendencies and their Relationship with ESL Proficiency: A Study of Chinese Students in Vellore, India. Pertanika Journal of Social Sciences \& Humanities, 25(2). 


\section{Copyrights}

Copyright for this article is retained by the author, with first publication rights granted to the journal.

This is an open-access article distributed under the terms and conditions of the Creative Commons Attribution license (http://creativecommons.org/licenses/by/4.0/). 